\title{
Forskerbestemoren og «kjøleskapsmødrene»
}

\author{
Da Eili Sponheim tok spranget fra pediatri til barnepsykiatri, møtte hun et fag der «kjølige mødre» fikk skyl- \\ den for barnas autisme og diagnoser kunne bli satt ved håndsopprekning. Det nøret opp under nysgjerrighet \\ og indignasjon på foreldrenes vegne og har resultert i 25 års forskning i fagfeltet.
}

- Det ville være et fryktelig scenario å vite svaret på alt, sier Eili Sponheim da jeg spør om det ikke er litt av en tålmodighetsprøve å forske år etter år. - Forskning og kunnskap åpner jo bare dører inn til nye rom der det ofte avdekkes landskaper du ikke kjente til da du startet. Det er så fascinerende å se at det meste er mer komplekst og interessant enn du var klar over da du begynte å dypdykke i et tema. Jeg blir bare mer og mer ydmyk, forklarer hun på sitt behagelige vis.

Av kolleger beskrives hun som pinlig nøyaktig og svært grundig, med et dryss av impulsivitet og et sprudlende humør. Sponheim er rett og slett en feiende flott dame, en sånn som man klamret seg til etter å ha hatt henne som underviser på studiet - fordi man trengte gode kvinnelige rollemodeller.

\section{«Kjøleskapsmødre»}

Da Eili Sponheim begynte som lege i barneog ungdomspsykiatrien i begynnelsen av 1980-årene, med en svært somatisk tilnærming til faget, fikk hun et realt kultursjokk. Det var en gryende akademisering av barne- og ungdomspsykiatri i 1981, møtte jeg familier til barn med autisme som var blitt påført mer lidelse enn hjelp i møtet med systemet. Det inspirerte meg til å gjøre noe for akkurat disse. Teorien om den kalde moren var en feilslutning basert på observasjoner av noen få kvinner som hadde strevd seg gjennom systemet og egentlig var kloke mødre for sine barn. Man så ikke hva barnet gjorde med foreldrene og at mødrene hadde egnede responser ut fra det autistiske barnets ikke-gjengjeldte følelser. Det disse mødrene gjorde, var å være tydelige, akkurat som barna deres hadde behov for. Slik ble altså den kloke mor oppfattet som kjølig og avvisende, forteller hun.

Den indignasjonen hun kjente og fortsatt kjenner på disse mødrenes vegne, har vært en sterk drivkraft i 20 års forskning i autismefeltet.

- Det er et økende antall barn som får autismediagnose?

- Straks vi fikk overbevisende studier om at autisme er en medfødt lidelse, ble det enklere å våge å stille diagnosen. Dernest

\section{«Vi kan ilke lenger lene oss mot enten miljø eller genetikk, men får en stadig større innsikt i hvordan dette griper inn i hverandre»}

faget. Teoriene til den engelske guruen sir Michael Rutters spredte seg, men hadde fortsatt ikke nådd frem i alle miljøer. Det var stort rom for personlige teorier om årsakssammenhenger, tilsvarende muligheter for personlige feil.

- Det vokste frem en rekke kulturer med sine helt egne meninger, forteller hun. - I enkelte miljøer hadde Leo Kanner fortsatt sterkt fotfeste med teorien om at årsaken til autisme var den kalde og avvisende moren som ikke tok imot barnet «kjøleskapsmoren».

- Hvordan opplevde du å komme fra somatikken til et fag som var så sterkt preget av personlige teorier uten vitenskapelig dokumentasjon?

- Da jeg begynte ved Statens senter for ble det som kalles Aspergers syndrom innlemmet i det vi nå betegner som autismespekterlidelsene. Det er erkjent at enkelte barn som har en tilnærmet normal utvikling av språk, evne til å lære og til å løse oppgaver de første leveårene, kan ha uttalte vansker i sosiale funksjoner, kvalitativt likt avviket de mest funksjonshemmede har. Disse fikk nok andre diagnoser tidligere.

\section{Biologisk orientert}

Det var da hun som helsestasjonslege, skolelege og pediater møtte barn som strevde at Eili Sponheim først fikk øynene opp for barne- og ungdomspsykiatrien som et aktuelt fagfelt å arbeide i. Erkjennelsen av at hun ikke visste hva hun skulle gjøre når hun møtte disse barna var frustrerende.
- Jeg hadde ikke noe greie på dette, og visste ikke hva jeg skulle gjøre for å hjelpe dem. Det var frustrerende å se dem streve så voldsomt $\mathrm{i}$ en periode av livet der de burde være på sitt aller flotteste, uten å kunne gjøre noe med det. Min egen utilstrekkelighet gjorde meg nysgjerrig på barne- og ungdomspsykiatrien som fag. - Var det vanskelig som biologisk orientert psykiater å vinne innpass og finne sin plass $i$ et fagfelt som i stor grad hadde fjernet seg fra somatikken?

- Med sterk forankring i somatikken var det vanskelig å svelge at diagnosesetting av barn hadde lav prioritet blant mange på den tiden. Jeg ble fort fratatt ideen om at jeg hadde en selvsagt plass i faget med min legeutdanning, ja, ler hun.

- Var det rom for somatisk tenkning?

- Mine teorier var knyttet tett opp mot somatikken, og med legeutdanningen var det nok lettere å vinne innpass i somatiske enn i psykiatriske miljøer på den tiden. Jeg syntes det var veldig uheldig at man fjernet seg fra somatikken den gangen, men nå vokser det frem en stadig økende erkjennelse av at skillet mellom biologi og psykologi er kunstig. Nå føler jeg meg hjemme i psykiatrifeltet, smiler hun.

\section{Diagnosevegring}

- Følte du noen gang at du mistet legeidentiteten?

- Nei, den har jeg holdt hardt på, men jeg har kanskje fått en mer ydmyk innstilling. Mental helse, ikke minst i utviklingen fra barn og frem til voksen alder, er et uhyre komplekst tema. Det behøves mange fagområder for å nærme seg dette. Hva er egentlig avvik og hva er normalvariasjon? Hva skal vi egentlig definere som barnepsykiatri? Det kan rett og slett være en utfordring å definere hvem som er de syke barna. Men en somatisk forankring har vært viktig for meg, understreker hun.

- Mange bekymrer seg for en økende grad av diagnosesetting på barn. Er man i barnepsykiatrien blitt vel ivrige til å klassifisere?

- Internasjonale tall tilsier at omtrent $10-25 \%$ av barne- og ungdomsbefolkningen har psykiske vansker. De fleste av disse vanskene er forbigående, men $5 \%$ av de unge vil ha behov for spesialistbehand- 


\title{
Eili Sponheim
}

\author{
Født 19.6. 1948
}

- Cand.med. Universitetet i Bergen 1973

- Dr.med. 1998 med avhandlingen Epidemiological and diagnostic aspects of childhood autism

- Spesialist i barne- og ungdomspsykiatri 1986

- Forskningsleder ved Klinikk for barn og unges psykiske helse, Oslo universitetssykehus, fra 2006

Foto SCANPIX

ling. I Norge er det gjort en omfattende studie (Barn i Bergen) der man fant litt lavere tall. Det er enighet om at det er flere barn og unge som strever enn de som kommer til BUP. Det er først i det siste at vi har kommet opp på $5 \%$-nivået $\mathrm{i}$ kapasitet til å ta imot barn og unge i spesialisthelsetjenesten, og det vil gi flere med diagnose. Basert på årsmeldinger fra poliklinikker kan det likevel se ut som vi fortsatt har et problem med diagnosevegring - mange får ikke diagnose selv om de kommer til BUP og får behandling der. Hvorfor så mange barn sliter, er et annet spørsmål.

\section{Pionerene}

- Hva var det som fikk deg til å bli værende i barne- og ungdomspsykiatrien til tross for frustrasjonen?

- Jeg var nok ikke alene om å ha et somatisk fotfeste, men vi var i et fåtall. Samtidig var det utrolig spennende å komme inn i et miljø med så mye kunnskap. Forskningsmiljøet var inne i en periode med gryende oppbygging. Med Ingrid Spurkland som overlege og Hilchen Sommerschild som professor ble vi virkelig stimulert til forskning. Jeg kom inn i miljøet på den tiden da pionerene var her, og de motiverte oss til å reise ut og utvikle vår kompetanse. Det var et spennende og berikende miljø da - og er det fortsatt. Det er noe jeg setter mer og mer pris på.

- Hvordan påvirker ny kunnskap om genetikk faget?

- Barne- og ungdomspsykiatrien blir et stadig mer spennende fag fordi det nå er en økende forståelse av hvordan miljø og biologi gjensidig påvirker hverandre. Vi kan ikke lenger lene oss mot enten miljø eller genetikk, men får en stadig større innsikt i hvordan dette griper inn i hverandre. Vi vet mer om hvor dynamisk hjernen er og hvordan genene kommer til uttrykk. I vårt fagfelt må vi ha en ydmyk holdning til kompleksiteten og en stor kontaktflate ut mot andre fagmiljøer.Vi får mer kunnskap om hvordan gener og miljø påvirker hverandre i menneskets utvikling, men vi avdekker nok ingen enkle sammenhenger mellom genetisk avvik og barnepsykiatriske tilstander. Det trengs imidlertid robust kunnskap for å redusere rommet for synsing.

- Debatten går høyt omkring $\mathrm{AD} / \mathrm{HD}$ diagnosen og medisinering av barn?

- Jeg vil hevde at det er høy grad av bevissthet innen BUP om å være tilbakeholden med medisinering av barn, og det brukes lite medisiner generelt. Det å vokse opp med et problem som gjør at du ikke fungerer, og den effekten dette har på hjernen, er det også viktig å være seg bevisst. Det har vært gjort studier der man ikke har påvist noen negativ effekt på den modne hjernen av at barn over seks år ble medisinert for AD/HD. Heller tvert imot, det var nemlig gunstig effekt av medisiner gitt på rett indikasjon. Barn under seks år kan vi ikke med sikkerhet gi en $\mathrm{AD} / \mathrm{HD}$-diagnose fordi diagnosekriteriene ikke er sikre i så lav alder. Derfor er terskelen for medisinering av så små barn høy - og skal være det. Dette er en av grunnene til at det nå gjennomføres en stor forskningssatsing i Norge som dreier seg om $\mathrm{AD} / \mathrm{HD}$ fra førskolealder, med oppfølging når barna er blitt åtte år. Studien krever store ressurser, og det har vi fătt til $i$ et samarbeid mellom Folkehelseinstituttet og Oslo universitetssykehus.

\section{Forskerbestemor}

Som mor til to og bestemor til fem har ikke Eili fritidsproblemer. Og det å være bestemor er ifølge Eili «bedre enn alt». - Som kliniker kan man jo få et skjevt bilde av barn. Men de fleste er robuste og mestrende, og det å ha barnebarn er en konstant påminnelse om dette.

Som bestemor reflekterer jeg over ting jeg ikke har tenkt over før, som for eksempel hvordan humor utvikles! Det er så fascinerende! Entusiasmen som inntar ansiktet idet samtalen dreies over på barnebarna, kan ikke skjules. Superbestemor er i farta, ingen tvil om det.

- Hva gjør du når du skal hygge deg uten barnebarn?

- Da leser jeg, gjerne detektivromaner. Det pirrer nysgjerrigheten min å nøste i mysterier.

- Er det noe av den samme nysgjerrigheten som driver deg som forsker?

- Ja, jeg kjenner igjen noe av det samme behovet for å samle løse tråder. Ellers er jeg glad i lyrikk og filosofi. Om jeg skulle studert igjen, kunne det gjerne vært filosofi. - Er du glad i naturen?

- Vi har en hytte på nordsiden av Hallingskarvet. Jeg liker det uforanderlige ved fjellene og naturen som ligger upåvirket av verden omkring.

- Er du toppturist?

- Jeg liker turer til fots og på ski, men lider i motbakkene. Å nå opp er derimot fantastisk. Det er veldig fascinerende, dette med fjelltopper. Det er egentlig akkurat som med forskningen: Når du er kommet opp på en fjelltopp, ser du bare uendelig mange flere topper som frister i det fjerne. De blir nok ikke blir besteget av meg, men av noen andre.

\section{Anne Kathrine Sebjørnsen}

annekaths@hotmail.com

BUP Nordstrand 